\title{
Insights into a Changing Communal Constructicon
}

\section{Legal Writing in the Late Middle Ages and Early Modern Period}

\begin{abstract}
The paper examines legal writing in the Late Middle Ages and Early Modern Period from a diachronic perspective. The underlying corpus consists of Middle Low German law codifications of the period from 1227 until 1567. Applying a constructionist approach, the focus lies on evolving and changing constructions (of legal writing). The corpus-based examination reveals insights into the changing communal constructicon. This communal constructicon can be seen as a repertoire of constructions shared by legal writers (of that time). Due to observable language elaboration processes, this repertoire - modelled as a socio-cognitive network - becomes increasingly complex and literate over time. Language elaboration is a type of language change closely linked to written usage. In this context, the obvious nexus between legal writing and language elaboration plays a crucial role.
\end{abstract}

\section{Introduction}

From a diachronic point of view, the paper aims to discuss (vernacular) legal writing in the Late Middle Ages and Early Modern Period. Thereby, focusing on emerging and evolving form-meaning pairs - constructions in the sense of Croft (2001) - as literate entities. From the perspective of corpus analysis, form-meaning pairs can appear as formulaic patterns in different corpora. Literate constructions emerge via processes of language elaboration (Maas 2008: 333). This type of language change is closely linked to writing and contexts surrounding the production of written documents. Especially legal texts - e. g. urban law codifications - can reveal interesting insights into this phenomenon. Within the period of investigation (1200-1600), legal texts have to meet growing requirements: They need to be as explicit and unambiguous as possible (Hiltunen 2012), but they must also construe an increasing number of varying legal situations and circumstances in a schematic and often compacted way (Tophinke 2009: 175-176,

2 Open Access. (C) 2020 M.-L. Merten, published by De Gruyter. (cc) BY This work is licensed under the Creative Commons Attribution 4.0 License. https://doi.org/10.1515/9783110669824-010 
2012). Subsequently, numerous literate form-meaning pairs coping with these demands evolve. Obvious examples are prepositional constructions (propositional integration) or different types of complex sentences (linking propositions to one another). Here, constructional changes and constructionalizations can be seen. Moreover, they serve as markers for a changing communal constructicon, a sociocognitive network of form-meaning pairs shared by legal writers of that period. Since the focus of research is on Middle Low German legislative documents, the paper not only deals with new data but also takes into account a much neglected historical language (Hundt and Lasch 2015: 3). Around the year 1600 - before the written language shift towards Early New High German was completed -, this historical stage of contemporary and nowadays (mostly) only spoken Low German had been highly elaborated. Following Maas (2009: 170), Middle Low German in those days was "fit to replace Latin in all linguistic domains". In the Early Modern Period, Middle Low German was a far-reaching and wide-spread written language: It functioned as the lingua franca of the Hanse area.

To capture the historical-diachronic dimension of elaboration processes, the corpus underlying this study consists of 13 urban law codifications from between 1227 and 1567 . Overall, it includes 244,140 words, whereby the shortest legal text (statutes of Werl of 1324) consists of only 1,400 words, the longest one (the urban law of Cleve from 1424/40) of about 70,000 words (for further infomation about the corpus cf. Merten 2018: 286-289). The qualitative research design includes the following steps and sub-objectives: (1) exploring the texts in their structural character and specific functionality (to regulate urban life), (2) identifying formmeaning pairs (in their function in legal texts) and (3) tracing their development over time (constructional change). Although the study is primarily qualitative in nature, frequencies of occurrence and changes of frequency can serve as important indicators: They indicate which recurrent patterns are most likely to have constructional status and where/when changes have presumably taken place. Beyond that, identified constructions and formulaic patterns - e. g. multiword expressions as construction evoking elements - are investigated regarding their social dimension. Here, it is relevant to consider an evolving legal style (Schwyter 1998: 190; Coupland 2007), for example, providing an explanation for retaining complex constructions that remain unchanged (e. g. theme indicating constructions).

The structure of this paper is as follows: Section 2 introduces language elaboration as a fundamental process of language change brought about by written usage. Cultural, cognitive and structural aspects of textualization phenomena are discussed and, in so doing, the language-historical setting is recapitulated. Section 3 provides an overview of key aspects of (diachronic) Construction Grammar 
research. The focus lies on (1) processes of constructionalization and constructional change and (2) the emergence and nature of communal constructica. In this context, pragmatic associations between certain linguistic entities - constructions - and typical usage events play a crucial role. Section 4 offers a closer look at the evolvement of Middle Low German legal writing (constructions) during the period of investigation. Selected examples are presented and discussed: firstly, restrictive constructions to construe exceptions to previous legal norms (section 4.1), and, secondly, theme indicating constructions (section 4.2). Section 5 briefly summarizes main aspects of the paper and gives an over- and preview of ongoing and further work (DFG-funded research project InterGramm).

\section{Cultural, Cognitive and Structural Textualization: Language Elaboration and Legal Writing}

The Late Middle Ages and Early Modern Period are mainly characterized by a growing importance of (vernacular) writing and written documents. Written texts play an increasingly integral role in cultural memory (Assmann 1992: 52). As a pivotal form of mediation, written records preserve knowledge detached from contexts of its production. Not only are written texts essential for recording knowledge but also for its transmission and dissemination. ${ }^{1}$ Law serves in this context as the domain par excellence: In the (Late) Middle Ages, urban life becomes increasingly complex, social relations grow and more and more legal claims are made. At this point, law serves as an (establishing) institution to control and regulate social situations and legal matters - e. g. how to behave as heir, seller, purchaser and so forth and what kind of punishment to expect when committing different crimes. Consequently, the older Latin law (not tailored to urban needs) is replaced by vernacular legal writing (Deutsch 2013; Wallmeier 2013; Warnke 1999). ${ }^{2}$ A rising number of urban communities starts to write down their

1 See Ong (1986: 38) in this context: "Knowledge itself is not object-like: it cannot be transferred from one person to another physically even in oral communication, face-to-face, or a fortiori in writing. [...] Since knowledge cannot be physically transferred verbally from one human person to another but must always be created by the hearer or reader within his or her own consciousness, interpretation is always in play when one listens or when one reads."

2 Maas (2009: 169) points out the following: "It took a long time to elaborate the vernacular languages so that they could articulate complex literate texts, and Latin served as the model: 
own municipal law, using already existing codifications of other cities as model. This growing use of the vernacular language for formal occasions and functions marks the starting point for the gradual rise and conventionalization of literate form-meaning pairs - viewed as processes of constructionalization and constructional changes as they are discussed in the following section in greater detail.

However, several further developments need to be pointed out as they have an impact on the constructional/structural dimension of legal writing, e. $g$. changing practices of reception: While the oldest Middle Low German law texts were meant to be read out to the public, the newer ones were meant to be read in silence to oneself (Erben 2000: 1585). This development from being read out to the urban community towards silent reading - as an adjustment of perspective is accompanied by several structural developments (Szczepaniak 2015: 109). It becomes increasingly important to produce texts "that will be consistent and defensible when read by different people at different times in different places" (Chafe 1982: 45). Correspondingly, structures supporting the independent comprehension of face-to-face contexts (have to) evolve (Maas 2009: 166): complex sentence types (e. g. subordinate constructions), modifying prepositional schemata, written text organizing constructions, several attributive techniques resulting in complex noun phrases and so on:

Written discourse develops more elaborate and fixed grammar than oral discourse does because to provide meaning it is more dependent simply upon linguistic structure, since it lacks the normal full existential contexts which surround oral discourse and help determine meaning in oral discourse somewhat independently of grammar.

(Ong 1982: 37)

Moreover, legal writing undergoes a noticeable professionalization within the period of investigation: Legal writers become experienced practitioners sharing their established and further elaborating routines of producing legislative texts. Urban chancelleries turn progressively into institutions of professional writing. At the same time, the proportion of citizens able to read increases over the Late Middle Ages (Maas 2001: 85; von Polenz 2000).

Consequently, numerous textualization phenomena at different levels start to emerge. The interwoven and corresponding dimensions are: the cultural, the cognitive-conceptual and the structural level (Schwyter 1998; Raible 1998). Structural textualization relates to the language-internal dimension. It manifests itself

Latin texts were 'sparring partners' for writers struggling to cope with these tasks. They had to calque Latin structures until a flexible literate grammar was also available in languages like German.” 
in the shape of grammatical and lexical elaboration (Koch and Oesterreicher 2007; Weber 2010), but is linked to the higher cognitive-conceptual textualization. Cognitive-conceptual textualization phenomena present themselves as (1) a "conceptual change of a whole discourse tradition from spoken to written" (Schwyter 1998: 190), but they also refer to (2) an increase in literate thinking (Raible 1998: 175). Writing makes a huge impact on thinking, it enables an intensive reflection on the text being produced, its planning and revision without communicative pressure. On the whole, structural and cognitive-conceptual textualization are driven by but also function as driving forces for a superordinate cultural textualization as "a culture's increasing use and acceptance of writing and literate modes" (Schwyter 1998: 190). As a consequence, literate societies (Goody 1986: 26) emerge, a form of community mainly based on and shaped by literacy (manuscript culture).

In sum: As has already been stated at several points, language elaboration is closely linked to writing and is a continuous development. Already existing constructions change and new literate form-meaning pairs emerge. From a grammatical point of view, constructionally complex schemata belonging to the formal register appear and evolve. The term literate refers to a linguistic coding in the form of sentences, the (functional) focus is on "addressing a generalized 'other', e. g. not presupposing a cooperative other for making sense of what is said, not relying on the situational context" (Maas 2009: 165-166). ${ }^{3}$ When we look at the range of evolving construction types, we can distinguish at least three phenomena of grammatical language elaboration (Merten 2018: 273): (1) the genesis of complex sentences/subordination (syntactically complex constructions), (2) the evolvement of integrating constructions (propositional integration, text compression) and (3) the gradual rise of constructions supporting the organization of written text (e. g. several coordinating constructions).

3 Maas (2001: 94) differentiates between orate and literate structures as follows: "One dimension of these style differences is explicitness or formality. At one extreme it is a strictly contextbound structure of utterances under control of face-to-face interaction, leaving most of what is said implicit. At the other extreme it is context-free articulation of an utterance, submitted to the formal demand of completeness with every piece to be articulated as a grammatical sentence, and permitting the reproduction of identical utterances in different context." 


\section{The Emerging Communal Constructicon: Constructionalization and Constructional Changes}

Before discussing the rise and change of constructions within Middle Low German legal writing, I will briefly introduce what constructions are and give a short summary of the most important aspects concerning constructions in use. Constructions are (cognitively stored) pairings of a meaning with a (mainly verbal) form. Moreover, their idiomaticity and/or high frequency in usage has to be emphasized:

Any linguistic pattern is recognized as a construction as long as some aspect of its form or function is not strictly predictable from its component parts or from other constructions recognized to exist. In addition, patterns are stored as constructions even if they are fully predictable as long as they occur with sufficient frequency.

(Goldberg 2006: 5)

Modelled as "formulaic, fixed sequences" (Bergs and Diewald 2008: 1), constructions differ in terms of complexity, schematicity and productivity (Goldberg 2006: 5). They range from single lexical entities (words) or morphemes with grammatical meaning to complex constructions with several schematic slots (e. g. argument structure constructions) being filled in usage. In this regard, not only does their form vary from simplex to complex but their meaning or function can also be to a greater or lesser extent specific/abstract (Ziem 2018: 9; Croft 2001: 17). Ziem and Boas (2017: 275) point out that so-called CEEs (construction evoking elements) can make up the lexical anchors of varying constructions. In view of partially specific constructions - the focus of section 4-, CEEs often fill those slots that are lexically fixed. In some cases, complex multiword expressions serve as evoking elements (Merten 2018: chapter 4). Overall, CEEs - whether lexical or grammatical/schematic - assume a decisive role in the constitution of constructional gestalts. They can thus project subsequent components or lead to a reinterpretation of preceding elements.

New form-meaning pairs arise due to (changing) communicative needs and are formed by communicative circumstances. Through language use, both form and meaning of a construction are subject to variation and change (Hoffmann and Trousdale 2011; Hilpert 2011, 2013; Filatkina 2014). In this regard, the majority of constructionist approaches - e. g. Cognitive Grammar, Radical Construction Grammar and Cognitive Construction Grammar - can be described as usagebased models (Hoffmann and Trousdale 2011: 4), following the guiding maxim 
that usage of a language shapes its structure and engenders change (Bybee 2010: 194; Langacker 2010: 94):

Unlike most other modern theories of linguistics, cognitive linguistics is a usage-based model of language structure (Langacker 1987: 46; 2008: 220). In other words, we posit no fundamental distinction between 'performance' and 'competence', and recognize all language units as arising from usage events. Usage events are observable, and therefore can be collected, measured, and analyzed scientifically (Glynn 2010: 5-6). In this sense, cognitive linguistics has always been a 'data-friendly' theory, with a focus on the relationship between observed form and meaning.

(Janda 2013: 2)

Consequently, realized constructions - constructs - are the "locus of linguistic innovation and subsequent change" (Trousdale 2013: 511). Emerging constructions may allow for a varying construal. This notion from Cognitive Grammar highlights the ability to construe one situation in different (linguistic) ways (Langacker 2015: 120). Linguistic meaning always encompasses both conceptual content and construal:

Content and construal are equally important aspects of the processing activity that constitutes linguistic meaning. They cannot be neatly separated (indeed, the selection of content is itself an aspect of construal). The rationale for distinguishing them is that the apprehension of a situation is more than just a representation of its elements. While content and construal are ultimately indissociable, the distinction draws attention to the flexibility of conception and the variability of expression even in regard to the same objective circumstances.

(Langacker 2015: 121)

For example, one conceptual content (CELEBRATE) can be construed as process (celebrate) or thing (celebration); a shift in profile $\mathrm{e}^{4}$ takes place:

(a) We celebrated all night.

(b) The celebration was great.

Depending on the communicative intentions, propositions and their relations can be construed differently - e. g. as a complex prepositional phrase (thing profile) or as a subordinate clause (process profile) - with the result that divergent images emerge (Langacker 2008: 55). Construal has to be viewed as a "multifac-

4 Cf. Langacker (2008: 98): “[W]hat determines an expression's grammatical category is not its overall conceptual content, but the nature of its profile in particular." 
eted phenomenon" (Langacker 1999: 5), encompassing the dimensions of specificity, focusing, prominence and perspective. All of these conceptual factors have in fact "manifestations in other sensory modalities" (Langacker 2015: 121), they rely on fundamental perceptive phenomena. In this context, Langacker (2015: 121) underlines the "primacy of vision and the grounding of cognition in perceptual and motor interaction".

Back to constructional change: In a diachronic perspective, as has already been pointed out, new constructions emerge and already existing ones are used in new contexts or change with regard to frequency, form or function. They are adapted to changing communicative circumstances (Tomasello 2003: 14). These processes can be accompanied by changes in degree of schematicity, productivity and compositionality. According to Traugott and Trousdale (2013: 20-21), two types of processes can be distinguished in this context: Constructional change has to be differentiated from processes of constructionalization. Whilst constructional change only affects one dimension of a construction (Hilpert 2011: 69, 2013), constructionalization involves the creation of a new form-meaning pair. Newly emerged constructions can make a huge impact on the overall boundary structure of the linguistic system. Viewing this structure as a (mental) network of related constructions - the so-called constructicon (Goldberg 2003: 220) -, emerging entities (form-meaning pairings) form new nodes and can thus change the whole network architecture. Both processes have in common that they are gradual in nature. Normally, only one constructional feature changes at a time and the observable steps are (very) small. ${ }^{5}$

A succession of small discrete steps in change is a crucial aspect of what is known as 'gradualness' (Lichtenberk 1991b). We understand 'gradualness' to refer to a phenomenon of change, specifically discrete structural micro-changes and tiny-step transmission across the linguistic system [...]. Synchronically it is manifest in small-scale cariation and 'gradience' [...]. This means that at any moment in time changing constructions contribute to gradience in the system.

(Traugott and Trousdale 2013: 74-75)

Focusing on the underlying corpus, it has to be pointed out that within one single text (as a synchronic form of the language/practice under investigation), the different stages of constructional change can surface as contextually determined variants (Heine and Narrog 2010: 409). Constructions of different ages exist side

5 "While there is no predetermined order for reanalyses at different constructional levels, the hypothesis is that pragmatic changes precede semantic changes; and these meaning changes precede formal changes" (Trousdale 2012: 543). 
by side and may be realized by one legal writer in one textual record. Hence, the distinction between synchrony and diachrony is not sharp, rather, synchrony and diachrony have to be viewed as an integrated whole (Bybee 2010: 105; Langacker 2010: 94). Here, the frequency of related constructions can reveal which variants are more or less entrenched and conventionalized at a given time. Generally speaking, a (relatively) high frequency of occurrences mirrors the typicality of the respective structure. From a cognitive point of view, high frequency (on token and/or type level) indicates a high degree of (constructional) entrenchment. A construction is very likely to be an entrenched and conventionalized entity at the time of its frequent usage (Bybee 2010: 81; for a further discussion concerning the connection of frequency, entrenchment and conventionalization see Schmid 2010, 2015). However, Traugott and Trousdale (2013: 5) note that the decision "what level of frequency is sufficient for pattern storage and entrenchment is problematic" and has to be modelled as relative and gradual (see also Langacker 2010: 94). This is particularly the case "in historical work where the textual record is often minimal" (Traugott and Trousdale 2013: 5).

Especially in the framework of usage-based Construction Grammar, constructions as schematized (often formulaic) patterns of language use can be thought of as entities also including information about the communicative usage events they are abstracted from (Langacker 2008: 458; Cienki 2015). ${ }^{6}$ Constructions can be enriched by pragmatic associations (Schmid 2014: 253). Repetitive language use contributes to the routinization of pragmatic associations: Due to the recurrent usage of form-meaning pairs in relatively stable communicative circumstances, a linkage between linguistic structures and "occasions when they were uttered" (Schmid 2014: 253) is established and becomes entrenched. This coinedness in discourse complies with the notion of "pragmatische Prägungen" discussed by Feilke (1996). Certain constructions can be "fitted to particular social actions" (Fox 2007: 312) performed linguistically, e. g. headline constructions in the context of (written) text production (Merten 2018: 443-451). In this respect, linguistic entities - single words, complex constructions, etc. - act as "keys adapted to different social contexts" (Maas 2001: 94). Inversely, they function as contextualization cues (Gumperz 1982: 131), evoking different contexts of speaking and writing when realized in actual usage events. They serve, for example, as key components for doing legal writing in the Late Middle Ages and Early Modern Period.

Legal writers in the Late Middle Ages and Early Modern Period - as (historical) community of practice - make use of a shared (and evolving) repertoire of

6 Cf. also Kristiansen and Dirven (2008); Hollmann (2013). 
constructions that are more or less enriched by pragmatic associations. These form-meaning pairings are linked to the usage event of creating legislative texts. As the circumstances and communicative constellations of the production and reception of legal texts alter, the repertoire of legal writing constructions undergoes a change as well. As pointed out in section 2, it becomes more complex and literate. A growing number of literate construal techniques evolves and the communal $^{7}$ constructicon - the socio-cognitive network of form-meaning pairs shared by legal writers - is elaborated.

By using these constructions, legal writers present themselves as members of a (professional) community and enact a certain social identity ${ }^{8}$. In this view, community membership is based on shared expertise/skills (Clark 1996: 102; Croft 2000: 939) referring to "the same in different individuals" (Schatzki 2002: 18):

The term community does not imply necessarily co-presence, a well-defined, identifiable group or socially visible boundaries. It does imply participation in an activity system about which participants share understanding concerning what they are doing and what that means in their lives and for their communities.

(Lave and Wenger 1991: 98)

\section{Legal Writing in the Late Middle Ages and Early Modern Period: Examples and Insights}

The main function of legal texts, especially of urban law codifications, lies in regulating and controlling urban life. Primarily, they have to construe what happens or has to be considered if a specific act is committed (e. g. murder, robbery, adultery, etc.) or an event has taken place (e. g. death resulting in an inheritance case). Accordingly, conditionality (if $\mathrm{X}$ then $\mathrm{Y}$ ) is a highly relevant semantic relation in this context. Several conditional construal techniques in their usage and change are discussed in Merten $(2017,2018)$ or Tophinke $(2009,2012)$. But an evolving distinctive legal style seems also to appear in the form of restrictive (sec-

7 See Croft (2000: 94) for the similar notion of communal lexicon as a "specialized vocabulary for a particular domain of shared expertise”.

8 Social identities are co-constructed within communities of practice: "In this view, as individuals interact with others in shared social practice, their actions - including common ways of speaking - shape and are shaped by their social identities" (Mallinson and Childs 2005: 1). 
tion 4.1) and so-called theme indicating constructions (section 4.2). In the following sections, the focus will be on partially specific constructions and formulaic ${ }^{9}$ expressions such as it si denn (dat) ('unless') or were it sake dat ('was it the case that') that serve as construction evoking elements (section 3). While the different slots of the respective constructions can be filled with varying contents/propositions depending on the legal scenario to construe/to regulate, these CEEs are relatively stable entities - 'relatively stable', because they are - on closer inspection - (also) subject to change.

\subsection{Construing Restrictive Relations: it ne si dat- and it si denn (dat)-Constructions}

Restrictive relations concern exceptions to (often) previously coded content. The oldest restrictive construal possibility realized in the (older) investigated legal texts is the exceptive clause. It is also discussed for Middle High German by Paul et al. (2007: 402). Structural properties evoking this construction (type) are the mononegation - often expressed by the negation particle ne/en - and the subjunctive (finite verb of the respective clause). These features are highlighted by bold print in the following examples:

(1) he heuet sine hant verloren he ne moge se weder kopen weder dat gerichte 'he has lost his hand, unless he can buy/purchase it against the law court'

(Braunschweig 1227)

(2) Dhes ne scal ene de uoghet nicht weldeghen. he ne winne it mit rechte 'Therefore, the bailiff shall not put him into possession, unless he wins it with law (justifiably)'

(Stade 1279; I:7)

In (early) Middle Low German, the mononegation can serve as a marker for restriction/exceptions because the contemporary negation of propositions is commonly realized by polynegation (cf. Breitbarth 2014 for the change of negation in Middle Low German). This exceptive clause as a restrictive construal technique is much more grammaticalized but less explicit than the emerging it ne si dat-construction - whereby si can be replaced by were ('was'). The it ne si dat-construc-

9 Cf. Wray (2002, 2008). 
tion gradually evolves during the 13th/14th centuries as the polynegation for negating (propositions and so forth) is replaced by mononegation. In consequence, the it ne si dat-construction represents an increasingly used linguistic option for construing an exception to preceding legal norms.

The multiword string it ne si/were dat - as lexical component of the relational construction - can be classified as a formulaic entity. Needless to say, the writing/spelling variation in historical times has to be considered in this context. The lexical entity encompasses the expletive it, the negation particle ne/en, a (mainly) subjunctive finite form of the copular verb $\sin$ ('to be') and the primary subjunction dat. Presumably, due to repetition in usage and thus frequency effects, chunking and fixing of a specific form of the exceptive clause - the recurrent instantiated predicative structure it ne si dat X - has taken place here:

Once word sequences such as be going to or in spite of have become frequent enough to be accessed from cognitive storage and produced as units, they begin to become autonomous from the words or morphemes that compose them. Both chunking and increase in autonomy are gradual processes, and the formation of a chunk (a storage and accessing unit) does not necessarily mean that speakers are no longer aware of the component parts and their meanings. That is, a sequence of words can become automated as a chunk through usage while a transparent relationship with the words in other contexts is maintained.

(Bybee 2011: 71)

The formulaic expression it ne si/were dat is used as a relating entity. Owing to its fixing and (presumable) reinterpretation, we can assume one overarching and non-compositional grammatical meaning that is undoubtedly more than the sum of its component parts (expletive it + negation particle + copular verb + subjunction dat). This functional word group construes the constraining relation between a (previous) content X (schematic slot I) and the content Y following this multiword string (schematic slot II). Subsequently, the syntagma it ne si/were dat + content Y (exception) is typically placed at the end of more or less complex paragraphs and articles (example 3). Sometimes, modifying adverbs are integrated into this multiword string, for example the form also ('therefore/thus', example 4):

(3) Hebbet lude lengu+ot in samender ha(n)t · sterft der en / de len eruen heuet · de binnen iren iaren $\sin \cdot$ wat men van ireme gu+ode vp nemet $\cdot$ dat scal men in weder gheuen wanne se to iren iaren komet $\cdot$ It ne were dat kost vp dat gu+ot ghe draghen were $\cdot$ de men redeliken bewisen mochte $\cdot$ der men nicht vmme ghan ne mochte $\cdot$ des scolen se ire del ghelden

'If people have fief together: If one of them dies who has fief heirs who are under their years: What one takes from their property, one shall give them back this property, 
when they come to their years. Unless (it is the case that) costs for the property incurred, one can prove in accordance with the legal norm, one could not avoid, they have to pay their share of it'

(Goslar 1350; Guardianship, § 9; Lehmberg 2013: 155)

(4) Hebben fe ouer nene kyndere to famende. vnde is de man voruluchtich. fo nemet fe ere medegyft to voren vt. van deme anderen $\int$ chal me ghelden de $\int$ chult. It en $\mathbf{S i}$ alzo dat fe mede ghelouet hebbe. Wante denne mo+et $\int e$ mede ghelden

'If they have no children together and the man is volatile, then, she removes her dowry afore. One shall pay the debt by the other. Unless (it is thus the case that) she has promised. Because then she has to pay'

(Oldenburg 1400; § 46)

It ne si/were dat provides not only the lexically fixed content of this restrictive form-meaning pair, it also serves as a construction evoking element (discussed in the previous section 3). Furthermore, it ne si/were dat can function as the profile determinant of a conditional construal technique: Legally recorded exceptions are often accompanied by construing what has to happen when the exceptional case comes to pass. In this way, it ne si/were dat relates a causing entity (exceptional case) and a thereby caused/initiated entity (consequence of the exceptional case) - both part of the construction ${ }^{10}$ - as can be seen in both examples 3 and 4.

We can also find evidence for it ne si/were dat-constructs combined with the exceptive adverb denne/dan ('except/but'). To be precise, these instances show a fusion of the two form-meaning pairs - the it ne si dat- and the denne-construction. Accordingly, the restrictive meaning is intensified as two restrictive techniques fuse:

(5) Ersloghe auer vser borghere en enne gast dod, dat scholde in sodanem rechte bliuen, alse dat wente her to ghestan heft · also dat de rad dar nene veste vmme don scholde . it en were denne dat de rad den gast ghe velighet hedde

'But, if one of our citizens slays a visitor, that has to remain in such a law as this has remained until now, namely, that the council therefore should undertake no fortification. Unless (it is the case that) the council had protected the visitor'

(Goslar 1350; Breach of the Peace, § 146; Lehmberg 2013: 325)

(6) Item Soe wylch(er) vand(en) ii vand(en) Raide dye sy dan dair inne wroegeden(n) dye en sall dan dair voir nyet neen seggen(n) then we(re) dan dat sy wroegeden(n) van segge worden offt van hoer(e)n seggen(n)

10 These more or less schematic entities - e. g. causing entity and caused entity - are part of the complex construction. They (can) show a specific word order (verb-final, verb-second, etc.) that can alter over time. 
'Item Which one of the two council commissioners, who they reprimand then, he cannot make an appeal to it, unless (it is the case that) they reprimanded for a complaint or due to hearsay'

(Duisburg 1518; plate 3, section 12; Mihm and Elmentaler 1990: 116)

Examples like these can be found until the early 16th century. In retrospect, they illustrate an intermediate stage in the ascent of the it si denn-construction - the most recent restrictive form-meaning pair relating two processual entities. Its constructionalization "can be seen to have arisen from a number of small local changes" (Traugott and Trousdale 2013: 29), so-called "pre-constructionalization constructional changes" (Traugott and Trousdale 2013: 36). According to the observations presented, a multiple inheritance leads to the creation of this (new) form-meaning pair (Trousdale 2013: 511): For at least two functionally related constructions (it ne si/were dat- and denne-construction) are involved in this constructionalization and they transmit formal and functional characteristics. In addition, the final stage is characterized by (i) the loss/elimination of the negation particle and (ii) the primary subjunction dat becoming only an optional element. It can be realized (examples 7 and 8), but it can also be left out (example 9):

(7) Wat averst syn liggende Gru+ende / und stahnde Erve / de mach ein Vormunder nicht verkopen / yt sy denn / dat der Kinder $\mathrm{u}+$ eterste Noht datsu+elvige erforderde 'But what his lying properties and standing bequest, a guardian is not allowed to sell those, unless the children's extreme misery requires it'

(Dithmarschen 1567; Article 71, § 2)

(8) §.4. It schall averst neen Vormunder der Unmu+endigen Huse / Ho+efe / Ackere / und andere liggende Gru+ende verkopen;

§.5. It ys denn / dat der Unmu+endigen Vader den Kindern so vele Schu+elde nahgelahten / dat de beweglyken Gu+eder tho betalinge dersu+elven nicht konden tholangen

'§.4. No guardian shall sell the house, courtyard, field and other lying property of the underaged;

$\S .5$. Unless the underaged's father left the children so much debt that the moveable property was not enough for its payment'

(Dithmarschen 1567; Article 22, § 4 and 5)

(9) NEEn Koep ys vo+er besta+endich tho holden / yt sy denn darby ein gewis Koepgeld bestemmet

'No purchase is valid, unless a certain purchase money is defined thereby'

(Dithmarschen 1567; Article 62, Introduction)

The it si denn (dat)-construction can very likely be categorized as a form-meaning pair typical of (historical) legal writing (Paul et al. 2007: 403). In this regard, it contributes to a legal style evolving in the period of investigation. As pragmatic 
association, this form-meaning pair is part of the (contemporary) communal constructicon (16th century). The development described from the exceptive clause to the it si denn (dat)-construction mirrors the changing repertoire of the legal writers. At different periods in time, different construal techniques serve as preferred strategies to construe exceptions - a highly relevant function in the production of legislative texts.

\subsection{Indicating an Overall Theme: the were it sake dat- Construction and Related Form-Meaning Pairs}

In the more recent urban law codifications investigated, a certain construction type (cluster of related constructions) indicating and introducing an overall (text/article) theme is used frequently. Here, the literate entity 'two-dimensional written text' plays a crucial role. The evolved constructions are tailored to this medial form designed for silent reading (as a visual-cognitive practice). From a diachronic viewpoint, a primarily conditional construal technique serves as source for (one micro-construction of) this construction type/construction cluster. But, with regard to the conditional usage, its text position is less restricted (source construction). This conditional form-meaning pair - with the CEE were it/dat sake dat meaning 'if' - can occur at different places in the article/paragraph.

(10) Vortmer wer dat sake dat eyn dem anderen scult gheue vor rychte eder vor den borgheren, [...] bu+ode dey eyn eyt, so eyn solde de andere vort den ghynen vor eyme anderen reychte vmme dey sake nicht mer sculdeghen

'Further, is it the case that one accuses the other in court or in front of the citizens [...], does he take an oath, then, the other shall henceforth not accuse this one for that issue in another court anymore'

(Werl 1324; § 24)

In constrast, theme introducing/indicating constructions have a relatively fixed position, which is restricted solely to the beginning of a new article or paragraph: At the beginning of the new article/paragraph the lexically fixed entity occurs as CEE (e. g. were it sake dat) followed by the theme/topic-slot that can be filled by diverging propositions (processual profile). This constructional characteristic can be viewed as textual coinedness (Feilke 1996: 281-282) implying that this formal feature of theme introducing/indicating constructions - their fixed position - is coined with respect to the written text and its characteristics. In addition, an expansion of function can be seen in these cases. Especially in the land law of Dithmarschen - the most recent legislative text investigated -, the were it sake 
dat-construction (see examples 11 to 13) not only construes a conditional relationship but marks the beginning of diverging articles and introduces their topic(s). Lehmann (1988: 187) has already pointed out that initial position usually indicates the topic of sentences:

Just as elsewhere, sentence-initial position usually identifies the topic (more precisely, the exposition, in the terms of Lehmann, 1984: ch. V.5) of the sentence. This is well-known from left-dislocated NPs. It is perhaps not so well known that a whole subordinate clause may also provide a topic for the following main clause.

(Lehmann 1988: 187)

In our context, this observation refers not only to sentences but also to more complex textual entities. Moreover, the recurrent multiword string were it sake dat (= lexically fixed elements) serves as a salient entity in view of its visual perceptibility; it can be easily perceived (and found in texts when searching for new paragraph beginnings). All in all, this construction type - besides serial numbering of the articles and so forth - is an aid to quick orientation in different parts of comprehensive text. This functional extension is brought about by writing and the two-dimensionality of written records. In the following examples from the land law of Dithmarschen, modifying adverb constructions (e. g. ok- ('also') and averconstructions ('but')) can be combined with this complex form-meaning pair:

(11) SO ener Schaden lede dorch syne Kleder / he worde gesteken / effte gehowen / so schall men ehm den Schaden behteren und nicht de Kleder.

$\S .1$. Were yt Sake / dat Se ehm ock anders syne Kleder thorehten hedden / dat bewyslyk were / so scho+elen Se ehm desu+elven betahlen / wat se wehrt syn.

$\S .2$. Und de Kleder scho+elen tho der Behoef / ...

'So/when one suffers harm through his clothes, he was stung or hit, then, one shall pay for his damage and not for the clothes.

$\S .1$. Is it the case that they also have to refund his clothes in another way, what is proven, then, they shall pay him these, what they are worth.

$\S .2$. And, for this purpose, the clothes shall ...'

(Dithmarschen 1567; Article 101)

(12) §.1. Were yt ock Sake / dat dar wol synem Volcke Schuld geve / u+emme jennig Guht / dat ehm entfehret were / dat schall he dohn / ...

'§.1. Is it also the case that there [one] likely blames his folks, for that property that was stolen from him, he shall do this ...'

(Dithmarschen 1567; Article 83, §1)

(13) §.1. Were yt averst Sake / dat he yt nicht bewysen konde / scho+elen beyde Ko+eper und Verko+eper schweren / dat eer Koep recht und redelyk / su+ender allen falsch und bedreechlicheit gegahn sy / so hoch alse se seggen ... 
'§.1. But is it the case that he cannot prove it, both, buyer und seller, shall swear that their purchase has happened fairly and honestly without any falsehood and deception/imposture, as high as they say ...'

(Dithmarschen 1567; Article 67, §1)

Although at first glance not closely related to each other, other multiword expressions evoking theme indicating constructions in the land law of Dithmarschen (1567) are begeve yt sick dat ('does it come to pass that'), droge yt sick to dat ('does it happen that') and befunde it sick dat ('does it take place that'). However, on closer inspection, they have a number of things in common: Typically, they share a finite verb in initial position (with the meaning potential 'happen/come to pass'), the subsequent expletive $y t / i t$, the reflexive pronoun sick and the primary subjunction dat. On this schematic level, these CEEs are in fact identical and in turn related to the more common were it sake dat as a fixed entity. The difference lies in the use of a construction with full verb(s) (zutragen ('happen'), befinden ('happen'), etc.) and processual profile vs. the use of one with a copular verb and the (legal) noun sake ('legal case') that allows a thing profile (section 3).

Interestingly, conditional construal techniques such as the efft-construction ('if'-meaning, a conditional relationship is profiled) merge with theme indicating/introducing constructions on the construct level. These fusion examples can be interpreted as supporting evidence for the specific functionality of the latter constructions. As has already been pointed out, it highlights the beginning of a new paragraph and is not only responsible for construing a conditional relationship. This function is realized by the efft-construction (examples 15 and 16):

(14) Effte ein Tu+ege Kranckheit halven tho Rechte nicht kamen konde.

Begeve yt sick / dat einer de tu+egen scholde / so schwack und kranck werde / dat he uht syner Behu+osinge vor Recht nicht kamen konde / so schalde Vaget...

'If a witness could not come to the court due to illness.

Does it come to pass that one who shall testify becomes so weak and ill that he cannot leave his house in order to come to court, then, the bailiff shall ...'

(Dithmarschen 1567; Introduction into Article 11)

(15) §.10. Efft yt sick ock begeve / dat enner / de Schaden gewunnen hadde / tweerley Worde fo+ehrede / alse / dat he den Schaden des Avendes geve up eenen / und des Morgens up enen andern / ys dat bewyslyk / so schall he ...

'§.10. If it also comes to pass that one who suffered damage conducts twofold words, such as that he attributes the damage to one person in the evening and to another in the morning, if this can be proven, then, he shall ...'

(Dithmarschen 1567; Article 94, § 10) 
(16) §.3. Effte sick denn befunde dat se ehres Gelovens nicht rein / und in ungo+ettlyker Schwermery steken / sick ock eines beteren nicht underwysen / und vanehren Erdohm wolden affleiden lathen / de scho+elen ahne Middel des Landes verwyset werden.

'§.3. If it takes place that they [are] not pure of their belief and are found in ungodly rapture, [they] also do not want to be open to conviction and disabused of their error, they shall be expelled from the country without funds.'

(Dithmarschen 1567; Article 2, § 3)

All in all, it is striking that these complex lexical entities are maintained and conserved although less complex alternatives - at least with a conditional meaning - exist. As Hoffmann and Trousdale (2011: 5) note, "if the same content can be expressed by two competing structures and one of these is easier to process than the other, then the simpler structure will be preferred in performance”. This consideration supports the very likely assumption of functionally charged formmeaning pairs in the case of the were it sake dat-, begeve it sick aver-constructions etc. discussed above (theme indicating, visualizing beginning of paragraph/article). In addition, the dimension of social value/meaning (Elspaß 2015) within a language community seems to play a decisive role. In contrast to existing less complex alternatives (efft- or wanne-constructions), these multiword expressions as CEEs (were it sake dat, befinde it sick dat, etc.) seem to offer a socio-pragmatic added value (in their simply larger gestalt, their distance marking use of subjunctive verb forms and so forth). ${ }^{11}$ In this context, legal writers are alluding to complex forms associated with skillful writing and prestigious language use in the Early Modern Period (Schwitalla 2002). In so doing, they underpin their professionality with the use of highly literate constructions that are part of their communal constructicon and which have evolved through the medium of writing.

\section{Conclusion}

The paper shed light on language elaboration processes in Middle Low German legal writing, whereby an underinvestigated historical language challenging (common) grammar theories became the central subject of investigation. Due to

11 However, the conservative nature of law needs to be considered in this context: "The law has to be revised constantly so as to keep it up to date with social change. This need for revision, however, does not mean that the language of the law will automatically be updated at the same time. On the contrary: since the law is essentially a conservative institution, it follows that its language is relatively conservative as well. It is therefore not likely to change very quickly." (Hiltunen 2012: 50) 
the diachronic research interest, an approach was adopted which was capable of coping with phenomena of language in transition and both formulaic (lexical) expressions and more complex form-meaning pairs between fixedness and variability: (Diachronic) Construction Grammar allows for the detailed description and explanation of changing form-meaning pairs, of observable relations between different constructions (as well as the development of these relations) and elements evoking those linguistic construal techniques (see also Filatkina 2018). Especially, the idiomatic/non-compositional nature of (grammatical) meaning was emphasized. Important processes in language change/usage such as reinterpretation and chunking as well as the idea of tiny-step transmissions played a crucial role. Source and target constructions were taken into account - whenever possible with regard to the underlying corpus - and a case of multiple inheritance where more than one form-meaning pair was involved in the creation of a new construction was discussed.

In particular, the focus was on the functionality of certain evolving constructions with regard to written text(s). Emerging constructions induced by writing can be viewed as literate entities and seem to be more complex than orate formmeaning pairs. They have to be interpretable independent of context and, thus, include all information necessary for comprehension. The nexus of language elaboration processes and legal writing was pointed out. Subsequently, attention was drawn to the adaption of vernacular language to literacy on the basis of urban law codifications produced over a period of more than 300 years (1227 to 1567). The evolving literate form-meaning pairs are increasingly tailored to (the production of) written texts structured for silent reading. In this legal context, important construal techniques concern conditional, causal or restrictive relations and so on. The combining of propositions and the changing ways of relating them linguistically are an interesting object of investigation. Certain constructions seem to be bound to legal writing, they can be modelled as pragmatic associations and are part of the changing communal constructicon of the historical community of legal writers.

InterGramm $^{12}$ - a Digital Humanities project at Paderborn University - continues this investigation of language elaboration processes in Middle Low German. Although the focus is on changing constructions, the underlying corpus consists of considerably more texts. Additionally, besides linguists, both computational linguists and computer scientists are part of the project team. By applying a human-in-the-loop approach, we combine phases of (human) expert annotation and machine learning. For the automatic construction tagging, we espe-

12 For further information: https://www.uni-paderborn.de/forschungsprojekte/Intergramm/ 
cially use (lexical) construction evoking elements. These important elements are (relatively) easily identifiable and useful for hypothesising what kind of construction might be instantiated. Especially in the historical context, annotating linguists have to be aware of a comparative fallacy that emerges when researchers fall into the error of investigating one language by comparing it to another, for example, their native language. The historicity of the language under investigation has to be given serious consideration. Historical languages must be viewed on the basis of their own common structures/constructions, characteristics and functionalities.

\section{References}

\section{Primary Sources (Cited Corpus Data)}

1227 urban law of Braunschweig: Wilhelm, Friedrich (1932): Corpus der altdeutschen Originalurkunden. Bis zum Jahr 1300. Band I: 1200-1282 (Nr. 1-564), 1-5. Lahr: Moritz Schauenburg K. G.

1279 urban law of Stade: Korlén, Gustav (1950): Das Stader Stadtrecht vom Jahre 1279, 23-117. Lund: C.W.K. Gleerup.

1324 urban law of Werl: Retrieved from http://www.lwl.org/331-download/Texte/html/20009 B.html, accessed August 20, 2018.

1350 urban law of Goslar: Lehmberg, Maik (2013): Der Goslarer Ratskodex - Das Stadtrecht um 1350: Edition, Übersetzung und begleitende Beiträge. Bielefeld: Verlag für Regionalgeschichte.

1400 urban law of Oldenburg: Korlén, Gustav (1951): Das mittelniederdeutsche Stadtrecht von Lübeck nach seinen ältesten Formen, 170-188. Lund: C.W.K. Gleerup.

1518 urban law of Duisburg: Mihm, Arend \& Michael Elmentaler (1990): Das Duisburger Stadtrecht 1518. Duisburg: Walter Braun.

1567 land law of Dithmarschen: Retrieved from https://books.google.de/books?id=t88pAAAAYAJ\&pg=PA189\&lpg=PA189\&dq=Dithmarsisches+landrecht\&source=bl\&ots=-PyV-dAWXt\&sig=0d1rEDzlbfcEvqJ2QDN0tsQTV-

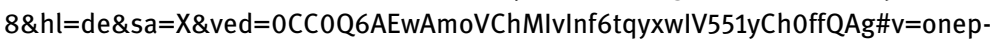
age\&q=Dithmarsisches\%20landrecht\&f=false, accessed August 22, 2018.

\section{Secondary Literature}

Assmann, Jan (1992): Das kulturelle Gedächtnis. Schrift, Erinnerung und politische Identität in frühen Hochkulturen. München: C. H. Beck.

Bergs, Alexander \& Gabriele Diewald (2008): Introduction: Constructions and Language Change. In Alexander Bergs \& Gabriele Diewald (eds.), Constructions and Language Change, 1-12. Berlin, New York: De Gruyter.

Breitbarth, Anne (2014): The History of Low German Negation. Oxford: Oxford University Press. 
Bybee, Joan (2010): Language, Usage and Cognition. New York: Cambridge University Press. Bybee, Joan (2011): Usage-based theory and grammaticalization. In Heiko Narrog \& Bernd Heine (eds.), The Oxford Handbook of Grammaticalization, 69-78. Oxford, New York: Oxford University Press.

Chafe, Wallace (1982): Integration and involvement in speaking, writing and oral literature. In Deborah Tannen (ed.), Spoken and written language. Exploring orality and literacy, 35-52. Norwood, New Jersey: Ablex.

Cienki, Alan (2015): Spoken language usage events. Language and Cognition 7 (4), 499-514.

Clark, Herbert H. (1996): Using language. Cambridge: Cambridge University Press.

Coupland, Nikolas (2007): Style. Language Variation and Identity. Cambridge, New York: Cambridge University Press.

Croft, William (2000): Explaining Language Change. An Evolutionary Approach. London: Longman.

Croft, William (2001): Radical Construction Grammar: Syntactic Theory in Typological Perspective. Oxford: Oxford University Press.

Deutsch, Andreas (2013): Historische Rechtssprache des Deutschen - Eine Einführung. In Andreas Deutsch (Hrsg.), Historische Rechtssprache des Deutschen, 21-80. Heidelberg: Universitätsverlag Winter.

Elspaß, Stephan (2015): Grammatischer Wandel im (Mittel-)Neuhochdeutschen - von oben und von unten. Perspektiven einer Historischen Soziolinguistik des Deutschen. Zeitschrift für germanistische Linguistik 43 (3), 387-420.

Erben, Johannes (2000): Syntax des Frühneuhochdeutschen. In Werner Besch \& Anne Betten (Hrsg.), Sprachgeschichte. Ein Handbuch zur Geschichte der deutschen Sprache und ihrer Erforschung, 1584-1593. Berlin, New York: De Gruyter.

Feilke, Helmuth (1996): Sprache als soziale Gestalt. Ausdruck, Prägung und die Ordnung der sprachlichen Typik. Frankfurt am Main: Suhrkamp.

Filatkina, Natalia (2014): Constructionalization, Konstruktionswandel und figurative Sprache (sprach)historisch betrachtet. In Martine Dalmas \& Elisabeth Piirainen (eds.), Figurative Sprache - Figurative Language - Langage figuré, 41-57. Tübingen: Stauffenburg.

Filatkina, Natalia (2018): Historische formelhafte Wendungen als Konstruktionen: Möglichkeiten und Grenzen der diachronen Konstruktionsgrammatik. Linguistik-Online 90 (3), 115143.

Fox, Barbara (2007): Principles shaping grammatical practices. Discourse Studies 9, 299-318.

Goldberg, Adele (2003): Constructions: A new theoretical approach to language. Trends in Cognitive Sciences 7 (5), 219-224.

Goldberg, Adele (2006): Constructions at work. Oxford: Oxford University Press.

Goody, Jack (1986): Funktionen der Schrift in traditionalen Gesellschaften. In Jack Goody, Ian Watt \& Kathleen Gough (Hrsg.), Entstehung und Folgen der Schriftkultur, 25-61. Frankfurt am Main: Suhrkamp.

Gumperz, John (1982): Discourse strategies. Cambridge: Cambridge University Press.

Heine, Bernd \& Heiko Narrog (2010): Grammaticalization and Linguistic Analysis. In Bernd Heine \& Heiko Narrog (eds.), The Oxford Handbook of Linguistic Analysis, 401-423. New York: Oxford University Press.

Hilpert, Martin (2011): Was ist Konstruktionswandel? In Alexander Lasch \& Alexander Ziem (Hrsg.), Konstruktionsgrammatik III. Aktuelle Fragen und Lösungsansätze, 59-75. Tübingen: Stauffenburg. 
Hilpert, Martin. (2013): Corpus-based approaches to constructional change. In Graeme Trousdale \& Thomas Hoffmann (eds.), The Oxford Handbook of Construction Grammar, 458-477. Oxford: Oxford University Press.

Hiltunen, Risto (2012): The Grammar and Structure of Legal Texts. In Lawrence M. Solan \& Peter M. Tiersma (eds.), The Oxford Handbook of Language and Law, 39-51. Oxford, New York: Oxford University Press.

Hoffmann, Thomas \& Graeme Trousdale (2011): Variation, change and constructions in English. Cognitive Linguistics 22 (1), 1-23.

Hollmann, Willem B (2013): Constructions in cognitive sociolinguistics. In Thomas Hoffmann \& Graeme Trousdale (eds.), The Oxford Handbook of Construction Grammar, 491-509. Oxford: Oxford University Press.

Hundt, Markus \& Alexander Lasch (2015): Das Niederdeutsche im Rahmen einer Sprachgeschichte des Deutschen. Jahrbuch für Germanistische Sprachgeschichte 6 (1), 3-17.

Janda, Laura (2013): Quantitative methods in Cognitive Linguistics: An introduction. In Laura A. Janda (ed.), Cognitive Linguistics: The Quantitative Turn. The essential reader, 1-32. Berlin, Boston: De Gruyter.

Koch, Peter \& Wulf Osterreicher (2007): Schriftlichkeit und kommunikative Distanz. Zeitschrift für germanistische Linguistik 35 (3), 346-375.

Kristiansen, Gitte \& René Dirven (eds.) (2008): Cognitive sociolinguistics. Language variation, cultural models, social systems. Berlin, New York: De Gruyter.

Langacker, Ronald (1999): Grammar and conceptualization. Berlin, New York: De Gruyter.

Langacker, Ronald (2008): Cognitive Grammar. A basic introduction. New York: Oxford University Press.

Langacker, Ronald (2010): Cognitive Grammar. In Bernd Heine \& Heiko Narrog (eds.), The Oxford Handbook of Linguistic Analysis, 87-110. Oxford: Oxford University Press.

Langacker, Ronald (2015): Construal. In Ewa Dabrowska \& Dagmar Divjak (eds.), Handbook of Cognitive Linguistics, 120-142. Berlin, Boston: De Gruyter.

Lave, Jean \& Etienne Wenger (1991): Situated Learning. Legitimate Peripheral Participation. New York: Cambridge University Press.

Lehmann, Christian (1988): Towards a typology of clause linkage. In John Haiman \& Sandra A. Thompson (eds.), Clause combining in grammar and discourse, 181-225. Amsterdam, Philadelphia: John Benjamins.

Maas, Utz (2001): Literacy in Germany. In David R. Olson \& Nancy Torrance (eds.), The making of literate societies, 82-100. Malden, Mass.: Blackwell.

Maas, Utz (2008): Sprache und Sprachen in der Migrationsgesellschaft. Die schriftkulturelle Dimension. Osnabrück: V\&R unipress.

Maas, Utz (2009): Orality versus literacy as a dimension of complexity. In Geoffrey Sampson, David Gil \& Peter Trudgill (eds.), Language complexity as an evolving variable, 164-177. New York, Oxford: Oxford University Press.

Mallinson, Christine \& Becky Childs (2005): Communities of Practice in Sociolinguistic Description: African American Women's Language in Appalachia. University of Pennsylvania Working Papers in Linguistics 10 (2), 1-14.

Merten, Marie-Luis (2017): Sociocultural Construction Grammar: Historisches Schreiben. In Meike Glawe, Line-Marie Hohenstein, Stephanie Sauermilch, Kathrin Weber \& Heike Wermer (Hrsg.), Aktuelle Tendenzen in der Variationslinguistik, 37-66. Hildesheim, Zürich, New York: Olms. 
Merten, Marie-Luis (2018): Literater Sprachausbau kognitiv-funktional. Funktionswort-Konstruktionen in der historischen Rechtsschriftlichkeit. Berlin, Boston: De Gruyter.

Ong, Walter (1982): Orality and Literacy. London, New York: Taylor \& Francis Group.

Ong, Walter (1986): Writing is a technology that restructures thought. In Gerd Baumann (ed.), The written word. Literacy in transition. Wolfson College Lectures 1985, 23-50. Oxford: Clarendon Press.

Paul, Hermann (2007): Mittelhochdeutsche Grammatik. 25. Auflage, neu bearbeitet von Thomas Klein, Hans-Joachim Solms \& Klaus-Peter Wegera. Tübingen: Niemeyer.

Polenz, Peter von (2000): Deutsche Sprachgeschichte vom Spätmittelalter bis zur Gegenwart. Band I: 14. bis 16. Jahrhundert. Berlin, Boston: De Gruyter.

Raible, Wolfgang (1998): B5 \& B12 Die Verschriftlichung der romanischen Sprachen (B5), Volkssprachliche Gattungen im europäischen Mittelalter (B12). In Wolfgang Raible (Hrsg.), Medienwechsel. Erträge aus zwölfJahren Forschung zum Thema ,Mündlichkeit und Schriftlichkeit', 163-192. Tübingen: Narr.

Schatzki. Theodore (2002): The Site of the Social. A Philosophical Account of the Constitution of Social Life and Change. Pennsylvania: State University Press.

Schmid, Hans-Jörg (2010): Does frequency in text instantiate entrenchment in the cognitive system? In Dylan Glynn \& Kerstin Fischer (eds.), Quantitative methods in cognitive semantics: Corpus-driven approaches, 101-133, Berlin, New York: De Gruyter.

Schmid, Hans-Jörg (2014): Lexico-grammatical patterns, pragmatic associations and discourse frequency. In Thomas Herbst, Hans-Jörg Schmid \& Susen Faulhaber (eds.), Constructions, Collocations, Patterns, 239-293. Berlin, Boston: De Gruyter.

Schmid, Hans-Jörg (2015): A blueprint of the Entrenchment-and-Conventionalization Model. Yearbook of the German Cognitive Linguistics Association 3 (1), 3-26.

Schwitalla, Johannes (2002): Komplexe Kanzleisyntax als sozialer Stil. Aufstieg und Fall eines sprachlichen Imponierhabitus. In Inken Keim \& Wilfried Schütte (Hrsg.), Soziale Welten und kommunikative Stile. Festschrift für Werner Kallmeyer zum 60. Geburtstag, 379-398. Tübingen: Niemeyer.

Schwyter, Jürg (1998): Syntax and Style in the Anglo-Saxon Law-Codes. In Christina Ehler \& Ursula Schaefer (Hrsg.), Verschriftung und Verschriftlichung. Aspekte des Medienwechsels in verschiedenen Kulturen und Epochen, 189-231. Tübingen: Narr.

Szczepaniak, Renata (2015): Syntaktische Einheitenbildung - typologisch und diachron betrachtet. In Christa Dürscheid \& Jan Georg Schneider (Hrsg.), Handbuch Satz, Äußerung, Schema, 104-124. Berlin, New York: De Gruyter.

Tomasello, Michael (2003): Constructing a Language. Cambridge, Massachusetts: Harvard University Press.

Tophinke, Doris (2009): Vom Vorlesetext zum Lesetext: Zur Syntax mittelniederdeutscher Rechtsverordnungen im Spätmittelalter. In Angelika Linke \& Helmuth Feilke (Hrsg.), Oberfläche und Performanz. Untersuchungen zur Sprache als dynamischer Gestalt, 161-183. Tübingen: Niemeyer.

Tophinke, Doris (2012): Syntaktischer Ausbau im Mittelniederdeutschen. Theoretisch-methodische Überlegungen und kursorische Analysen. Niederdeutsches Wort 52, 19-46.

Traugott, Elizabeth Closs \& Graeme Trousdale (2013): Constructionalization and Constructional Change. Oxford: Oxford University Press.

Trousdale, Graeme (2012): Grammaticalization, lexicalization and constructionalization from a cognitive-pragmatic perspective. In Hans-Jörg Schmid (ed.), Cognitive Pragmatics, 533558. Berlin, New York: De Gruyter. 
Trousdale, Graeme (2013): Multiple inheritance and constructional change. Studies in Language 37 (3), 491-514.

Wallmeier, Nadine (2013): Sprachliche Muster in der mittelniederdeutschen Rechtssprache: Zum Sachsenspiegel und zu Stadtrechtsaufzeichnungen des 13. bis 16. Jahrhunderts. Köln: Böhlau.

Warnke, Ingo (1999): Wege zur Kultursprache. Die Polyfunktionalisierung des Deutschen im juridischen Diskurs (1200-1800). Berlin, New York: De Gruyter.

Weber, Beatrice (2010): Sprachlicher Ausbau. Konzeptionelle Studien zur spätmittelenglischen Schriftsprache. Frankfurt am Main: Peter Lang.

Weber, Beatrice (2015): „the seid acte, statute or ordenaunve, or eny other made to the contrary, notwithstondyng": Zur Rolle der Faktoren 'Diskurstradition' und 'Sprachkontakt' bei der Etablierung der notwithstanding-Konstruktion im Englischen. In Alexander Ziem \& Alexander Lasch (Hrsg.), Konstruktionsgrammatik IV. Konstruktionen als soziale Konventionen und kognitive Routinen, 225-241. Tübingen: Stauffenburg.

Wray, Alison (2002): Formulaic Language and the Lexicon. Cambridge: Cambridge University Press.

Wray, Alison (2008): Formulaic Language: Pushing the Boundaries. Oxford, New York: Oxford University Press.

Ziem, Alexander (2015): Desiderata und Perspektiven einer Social Construction Grammar. In Alexander Ziem \& Alexander Lasch (Hrsg.), Konstruktionsgrammatik IV. Konstruktionen als soziale Konventionen und kognitive Routinen, 1-25. Tübingen: Stauffenburg.

Ziem, Alexander (2018): Construction Grammar meets Phraseology: eine Standortbestimmung. Linguistik-Online 90 (3), 3-19.

Ziem, Alexander \& Hans C. Boas (2017): Towards a Constructicon for German. Proceedings of the AAAI 2017 Spring Symposium on Computational Construction Grammar and Natural Language Understanding, 274-277. 